\title{
Mobbning: ett tidsbundet socialt problem?
}

\author{
ANNA LARSSON
}

I denna artikel diskuteras mobbning som ett socialt problem. Här visas hur en medial debatt uppstod 1969 och hur mobbning i och med detta konstruerades och etablerades som ett socialt problem. Särskilt fokuseras begreppsformuleringens betydelse.

Vad som i samhället uppfattas och beskrivs som ett socialt problem varierar över tid. Tittar man i en dagstidning eller en socialvetenskaplig tidskrift från exempelvis början av 1900-talet känner man igen somliga problem som behandlas medan andra tycks tämligen främmande. För mig som idéhistoriker med forskningsintresse bland annat för kunskapen om det sociala och om samhället framstår de sociala problemens historicitet som ett väldigt spännande undersökningsområde av central relevans. I denna artikel vill jag utifrån detta intresse

Anna Larsson, docent, Institutionen för idé- och samhällstudier, Umeå universitet. diskutera ett specifikt socialt problem, nämligen mobbning. ${ }^{1}$

Idag presenteras mobbning som ett allvarligt och viktigt problem inom såväl skola som arbetsliv. Mängder av texter om ämnet publiceras: böcker, vetenskapliga artiklar, debattinlägg eller skönlitterära skildringar. Många människor kan vittna om egna eller andras erfarenheter av att bli utsatta för mobbning och kan berätta om kränkningar av mobbningskaraktär från

1 Denna text har tillkommit inom ramen för min forskarassistentbefattning som finansierats av Vetenskapsrådets utbildningsvetenskapliga kommitté. 
länge tillbaka som gett bestående minnen. I Sverige har under senare år ett antal »fall" genom medias försorg blivit rikskända, ett i Grums och ett i Sävar för att nämna några, där drabbade skolelever har krävt ekonomisk kompensation av ansvariga myndigheter för den kränkande behandling de utsatts för.

Mobbning har emellertid inte alltid rönt denna uppmärksamhet eller haft denna laddade betydelse. Det är först från slutet av 1960-talet som mobbning i en skandinavisk kontext började uppfattas som ett problem i samhället värt att diskutera och försöka åtgärda, och en internationell vetenskaplig diskussion om mobbningsproblematik växte fram först på 1980-talet. Detta innebär emellertid knappast att det som vi nu kallar mobbning inte förekom dessförinnan, och det var med all sannolikhet plågsamt för många som drabbades redan då. Men mobbning diskuterades inte allmänt som ett problem, något som också innebar att det inte var aktuellt med några åtgärder eller lösningar.

Syftet i denna artikel är att, utifrån teorier kring sociala problem, diskutera uppkomsten av mobbning som ett socialt problem med särskilt fokus på begreppsformuleringens betydelse.

\section{Vad är sociala problem och är mobbning ett sådant?}

Det finns många sätt att se på vad ett socialt problem är. Som exempelvis Meeuwisse och Swärd (2002a) och Rubington och Weinburg (2003) konstaterar har sociala problem inte någon självklar definition och förståelsen av vad som ska betraktas som sociala problem varierar inte bara över tid utan också mellan olika sammanhang idag. Utifrån ett antal uppslagstexter har Meeuwisse och Swärd (2002a: 37-39) emellertid urskiljt sju aspekter som enligt definitioner och förklaringar i generell mening karaktäriserar sociala problem. Har mobbning dessa karaktäristiska drag?

För det första har ett socialt problem med den sociala sfären att göra och kan inte reduceras till att vara enbart ett ekonomiskt eller politiskt problem. Även om definitioner och grundläggande förklaringsmodeller delvis skiljer sig åt inom mobbningsforskningsfältet (Macklem 2003: 1-7, Smith et al 1999: 1-2) handlar mobbning i generell mening om socialt samspel, om individ och grupp och är något som förekommer i sociala sammanhang, möjligen enbart i formaliserade sociala ordningar (Eriksson 2001: 16-17). För det andra är ett socialt problem per definition något oacceptabelt, det uppvisar ett stort avstånd mellan det önskade och det oönskade. Vad som är oacceptabelt kan variera mellan olika tider och olika sammanhang. Tveklöst uppfattas mobbning idag som en oacceptabel situation för de drabbade och som en oönskad företeelse i skola och samhälle.

Ett socialt problem gäller för det tredje inte privata bekymmer utan har med samhällets struktur och organisation att göra (jfr Mills 1985: 27-29). Många idag anser att mobbning i skolor eller på arbetsplatser inte bara är ett bekymmer för drabbade eller på andra sätt inblandade individer utan är ett problem med mer allmän och vidsträckt relevans som har med strukturella eller värderingsmässiga faktorer att 
göra. Ett socialt problem omfattar för det fjärde ett betydande antal personer eller förefaller vara något som ökar. Många studier har undersökt förekomst och frekvens av mobbning i exempelvis skolsammanhang och olika uppgifter har presenterats (Smith et al 1999, Varhama 2008, Skolverket 2009). Även om siffrorna varierar tycks det ovedersägligt att mobbning drabbar ett betydande antal elever i skolan i Sverige såväl som $i$ andra länder.

En femte aspekt som lyfts fram är att ett socialt problem kan och bör åtgärdas. Den mängd av åtgärdsprogram och metoder som florerar idag visar att mobbning uppfattas som möjligt att åtgärda och knappast någon anser det överflödigt med insatser mot mobbning (jfr Skolverket 2009). Karaktäristiskt för ett socialt problem är för det sjätte att ansvaret för att åtgärda det ligger på samhället. Att det finns lagar som omfattar mobbningshändelser och att skolor är skyldiga att upprätta handlingsplaner visar att ansvaret för mobbning idag ligger på skola och samhälle och inte (enbart) på individuella förövare eller offer.

För det sjunde är ett socialt problem på ett eller annat sätt synligt. Genom att tidningar och TV rapporterar om mobbningshändelser finns en medial synlighet. Men också i och med att fritidspersonal och andra finns i barnens lekmiljöer och att de vuxna riktar stor uppmärksamhet på barnens kamratsamspel torde mobbning kunna synas åtminstone ibland när den förekommer i skolmiljöer.

Mobbning kan alltså betraktas som ett socialt problem enligt samtliga av de aspekter som Meeuwisse och Swärd pekar ut. Det jag vill visa är att detta uppstod vid en viss tidpunkt, det vill säga mobbning blev ett socialt problem vid en viss tid och jag kommer särskilt att lyfta fram betydelsen av begreppsformuleringen.

En tidssituerad uppkomst är förstås inte unikt för just mobbning som socialt problem. Arbetslöshet kan nämnas som ett annat exempel i svensk historia. Under 1800-talet betraktades arbetslöshet vanligen som ett problem hos den enskilde individen (och dennes familj) eftersom det ansågs bero på individuell ovilja att ta arbete eller oförmåga att behålla ett arbete. Under senare delen av 1800-talet började emellertid radikala sociala debattörer att driva uppfattningen att samhället skulle genomföra åtgärder för att minska arbetslösheten eftersom det inte fanns tillräckligt med arbeten till alla, och eftersom också det samhällsgemensamma skadades av att enskilda personer inte kunde försörja sig. I samband med detta förändrades synen på arbetslöshet så att den alltmer betraktades som ett gemensamt socialt problem (Olofsson 1997). Som Edling (1996: 48) har påpekat hade en förändrad begreppsanvändning betydelse också när det gäller arbetslöshetsfrågan. Andra exempel på sociala problem vars tidsbundenhet studerats av svenska forskare är drogbruk (Lindgren 1993) och hemlöshet (Swärd 2008).

För att förklara den tidsbundna uppkomsten kan man skilja på manifesta och latenta problem. På det sättet kan det förklaras att vissa företeelser i en viss tid i ett visst samhälle är definierade som problem, medan andra inte erkänns som problem trots att de på ett eller annat sätt kan urskiljas som problematiska i förhållande till rådande strukturer, rådande normer, 
önskad funktion eller något annat (Meeuwisse \& Swärd 2002b: 98, Merton \& Nisbet 1966: 788).

Talar man om manifesta och latenta problem utgår man från tanken att problemet finns där även när det ännu inte har upptäckts. Detta brukar kallas ett objektivistiskt synsätt. Sociala problem betraktas som yttringar av faktiska missförhållanden, att de på ett eller annat sätt springer ur rådande sociala förhållanden som i sig är faktiskt problematiska. Olika termer används i den svenska forskningslitteraturen på området men en vanlig uppdelning är att ställa objektivistiska (essentiella eller realistiska) synsätt mot konstruktivistiska (eller relativistiska) synsätt, där de sistnämnda betonar den "kollektiva definitionsprocessu som krävs för att sociala problem ska etableras (Nilsson 2003: 23-25; Lindgren 1993: 34, Estrada 1999: 19-29, Sahlin 2002: 109-120, Meeuwisse \& Swärd 2002b: 97-98). Det konstruktivistiska synsättet lyfter fram betydelsen av själva formuleringen av ett problem, den process där ett fenomen börjar betraktas som problematiskt. I teorier om konstruktionen av sociala problem uppmärksammas bland annat vilka retoriska grepp som drivande aktörer använder i sin problemformulering, vilka publiker anspråksformeringen riktar sig mot, vilka argument som anförs som skäl att uppmärksamma problemen och vilka lösningar som förs fram som möjliga och önskvärda (Loseke \& Best 2003, Loseke 2003).

Att ha en konstruktivistisk utgångspunkt innebär att skilja på vad som kan uppfattas empiriskt - sociala fenomen eller sociala förhållanden - och huruvida dessa betraktas som problematiska (Bash 1995: 29). Det kanske främsta argumentet för det konstruktivistiska synsättet är att vi aldrig kan särskilja de objektiva, reella grunderna för sociala problem utan alltid uppfattar och ger innebörd åt problem genom hur vi formulerar dem. Det kan inte finnas någon problembeskrivning som inte är på ett eller annat sätt konstruerad. Även om man inser detta kan man hävda att till exempel mobbning utgör reellt existerande missförhållanden. Likaså kan man behålla en objektivistisk utgångspunkt även om man uppmärksammar att problem kan definieras olika beroende på varierande utgångspunkter och skilda intressen. Även innan man talade om mobbning som ett problem kan det förmodas ha existerat som företeelse. Rimligen kan det knappast ha upplevts som annat än problematiskt för en drabbad individ. Samtidigt kan formuleringen av problemet ha betydelse för hur man upplever och tolkar sin situation.

Detta är min utgångspunkt. Det jag främst har undersökt är hur mobbningsfenomen kom att få uppmärksamhet och hur de började betraktas som viktiga sociala problem. Jag tror, allmänt sagt, att företeelsen fanns redan innan den formulerades i ord men jag tror också att formuleringen av den faktiskt bidrog till hur den upplevdes och uppfattades av såväl drabbade som myndigheter och allmänhet. Jag utgår således från att det finns både en objektiv och en konstruerad aspekt i det sociala problemet mobbning.

Vad var det då som hände när mobbning började uppmärksammas som ett socialt problem? Här finns flera aspekter som kan uppmärksammas. Först och främst vill 
jag lyfta fram mobbningsbegreppets formulering, vad som kan kallas den första konstruktionen av problemet. Efter en kort beskrivning av mobbningsdebattens utveckling tar jag upp några orsaker till att det nya begreppet fick en snabb spridning samt några reflektioner kring varför företeelsen rönte uppmärksamhet i samtiden. Slutligen återknyter jag till diskussionen om mobbning som ett socialt problem.

\section{Det nya mobbningsbegreppet}

År 1969 började termen mobbning att användas för ett beteende bland människor. Det var läkaren Peter Paul Heinemann som introducerade termen mobbning - eller med dåtidens språkbruk mobbing - $\mathrm{i}$ ett temanummer av tidskriften Liberal debatt. Temanumret handlade om apartheid, en fråga som i tiden var högaktuell och livligt omdiskuterad. Heinemanns artikel var också betitlad "Apartheid" och det är i detta sammanhang som mobbningsbegreppet först formulerades. Med apartheid avsåg Heinemann inte specifikt ett samhällssystem utan mer en attityd hos människor, en attityd där åtskillnad, isolering och främlingskap är centrala element. Mobbning är ett beteende där skolbarn i grupp fysiskt eller psykiskt angriper ett enskilt barn och det är, skriver Heinemann, ett första steg mot apartheidattityden. I sin artikel kräver Heinemann att mobbning ska anses oacceptabelt och motarbetas på alla fronter.

En närmare analys av Heinemanns beskrivning av mobbning visar hur problemet inledningsvis konstruerades. I sin artikel hävdar Heinemann att mobbning är mycket allvarligt både för drabbade individer, som kan få hela livet "ödelagt" och ur samhällelig synvinkel i och med att han kopplar mobbning till ord som apartheid, pogromer och folkmord (Heinemann 1969: 9-13).

Som förklaring till fenomenet anför Heinemann en teori som grundar sig i etologen Konrad Lorentz bok om aggressionens natur (Lorenz 1967). Aggression och entusiasm har samma ursprung i människans natur, den ena destruktivt inriktad och den andra konstruktivt. Mobbning är en form av aggression/entusiasm som uppkommer i grupper som befinner sig i situationer där känslan inte får utlopp på något alternativt sätt. Sådana situationer uppkommer oftare i stora grupper än i små och oftare i storstäder än på landsbygd. I stadssamhällen finns färre konstruktiva lekmöjligheter som kan kanalisera entusiasmen. För ett potentiellt drabbat barn finns det dessutom i staden färre möjligheter att komma undan. Heinemanns förklaringsmodell innehåller således både biologiska, sociala och strukturella aspekter.

Som Heinemann ser det förekommer mobbning således hos människan i hennes egenskap av flocklevande djurart och utlöst av situationella orsaker av samhällelig karaktär. Man kan emellertid möta beteendet på skilda sätt och här menar Heinemann att vuxenvärlden blundar när barn mobbar varandra. Den lösning på problemet som han för fram, eller snarare det som han ser som nödvändigt att åstadkomma, är alltså en attitydförändring. Högsta prioritet måste ges åt vad Heinemann kallar human fostran: "en fostran eller indoktrine- 
ring mot mobbtendenserna och apartheidbeteendena" (Heinemann 1969: 13).

På detta sätt formulerade alltså Heinemann problemet mobbning. Genom att dels koppla företeelsen till i samtiden aktuella samhällsföreteelser som apartheid och det moderna storstadssamhället och dels anknyta till en vetenskaplig terminologi gav han begreppet ett slags legitimitet.

\section{Växande intresse för mobbning}

Då begreppet introducerats kom det snabbt till flitig användning. Redan 1970 förekom termen i Svenska modeord (Panelius \& Steinby 1970). Att spridningen snabbt tog fart kan främst tillskrivas en stort uppslagen artikelserie i Dagens Nyheter, där journalisterna Anna-Maria Hagerfors och Birgitta Nyblom (1969a, 1969b, 1969c, 1969d, 1969e samt 1969f) lyfte fram Heinemanns nya begrepp och gav det en synlighet som hans egen artikel i Liberal debatt aldrig kunnat komma i närheten av. Artikelserien gavs 1970 ut som ett särtryck (Dagens Nyheter 1970) vilket ytterligare visar på det stora genomslag som serien fick. I första och sista artikeln ges ordet till Heinemann och i övriga artiklar får elever, föräldrar, lärare och en rad experter komma till tals. Även Konrad och Margarethe Lorenz, som besökt Stockholm för ett Nobelsymposium, har svarat på några frågor från reportrarna (Hagerfors \& Nyblom 1969a).

En synnerligen livlig medial debatt uppstod med Dagens Nyheters artikelserie, mobbning debatterades i många samman- hang och begreppet spreds (Agevall 2007, Agevall 2008). Med denna medialisering skedde en fortsatt konstruktion av mobbningsproblemet. I Dagens nyheters artikelserie, till exempel, är tanken om offret som avvikande central, mer central än hos Heinemann. Man kan också se att Heinemanns idé om mobbning som ett spontant utlöst gruppburet aggressionsuttryck inte får särskilt stor tyngd; istället dominerar individuella förklaringsfaktorer (Larsson 2008b).

Mobbning rönte snart även vetenskapligt intresse. Psykologen Dan Olweus inledde sin omfattande forskningsverksamhet på området i början av 1970-talet (Olweus 1973). Med Olweus som pionjär och forskningsledare kom en "skandinavisk forskningstradition" att utvecklas under 1970- och 1980-talen (Roland 1988, Björkqvist \& Varhama 2008). Inom denna tradition intresserade sig forskarna främst för den individuella dispositionen och man undersökte vilka personlighetsegenskaper som mobbare, mobboffer och medlöpare hade. Förutom intresset för de roller som kan urskiljas i en mobbningsrelation ägnades en stor del av forskningen åt att undersöka mobbningens förekomst och frekvens i olika miljöer och åldrar (Fors 1993: 21). Under andra hälften av 1980-talet började intresset för mobbning spridas internationellt (Roland \& Munthe 1989, Smith \& Sharp 1994). Ungefär samtidigt började också mobbning bland vuxna på arbetsplatser att undersökas (Leymann 1986, Varhama 2008). Det är påtagligt hur de forskningsfrågor som hade etablerats i den tidigaste skandinaviska forskningen också följde med när intresset för mobbningsföre- 
teelsen spreds över världen (Eriksson et al 2002, Smith et al 1999).

Mobbning har således studerats i forskning sedan tidigt 1970-tal. Det mediala intresset har emellertid varierat $\mathrm{i}$ intensitet (Larsson, 2010). Den tidigaste debattvågen gällde främst mobbning mellan barn i skolsammanhang. Då man vid mitten av 1980-talet började tala om mobbning bland vuxna på arbetsplatser ökade intresset från medias sida åter. Också de rättsfall som förekommit sedan 1990-talet har renderat stort medialt intresse.

I och med medialiseringen och forskningsintresset har mobbning uppenbarligen blivit känt, fått en synlighet och etablerats som ett angeläget problem för skola och arbetsliv. Här vill jag lyfta fram en särskild aspekt i problemets konstruktion, nämligen själva begreppet. Vilken betydelse hade begreppsutformningen för hur mobbning kom att förstås som ett socialt problem? Vad kan det ha berott på att det nya begrepp som Heinemann presenterade 1969 kunde accepteras och anammas och snabbt bli allmänt känt? Man kan finna flera skäl till det snabba genombrottet.

\section{En känd term}

Termen mobbning, eller mobbing som var den ordalydelse som initialt användes, var språkligt sett inte alldeles ny. Heinemann uppgav att han hämtat den från Konrad Lorenz etologiska populärvetenskapliga arbete Aggression: Dess bakgrund och natur (1967). För Lorenz och andra som studerat fåglar var mobbing ett sedan början av 1900-talet känt beteende som innebär att en grupp av en underlägsen art attackerar en individ ur en överlägsen fiendeart. Detta skedde emellertid, hade ornitologer noterat, i situationer där den hotfulla fågeln var försvagad som till exempel när en nattjagande uggla mötte en flock småfåglar under dagtid. Samtidigt hade man iakttagit att fågelungar inte med självklarhet tycktes vara rädda eller fientligt inställda mot artens naturliga fiender. Därför antog man att mobbingen här hade ytterligare en funktion i att lära ungfåglar vilka de behövde fly undan (Hegelbach 2003).

När Heinemann beskriver detta beteende bland barn försvinner emellertid den aspekt ur det etologiska mobbingbegreppet som innebar att den drabbade är en överordnad som flocken har en chans mot enbart i kraft av att de är många och att den överlägsna är försvagad. Mobbing blir den företeelse när en grupp barn attackerar en ensam utsatt individ.

Denna betydelseglidning uppmärksammades emellertid knappast utan termen spreds snabbt. Kanske gav mobbningens ursprung som ett fågelbeteende det en vederhäftig klang, något som kan noteras även hos begreppet "hackordning" som i likhet med mobbning som metafor överförts från fåglars värld till barns (Larsson 2008a). Det förefaller sannolikt att termen inte kändes alltför främmande och här kan dess tidigare användning i etologin ha haft en betydelse. Det var säkert också centralt att termen kunde associeras till mobb och mobbens beteende, något som socialpsykologer diskuterat sedan sent 1800-tal. Man hade försökt förstå hur människor kunde agera så synbarligen annorlunda $\mathrm{i}$ en folkmassa 
än vad de gjorde som individer (King 1994, Larsson 2008b). Mobbing kunde förstås som ett särskilt slags aggressivt mobbeteende, något som uppfattades vara särskilt vanligt bland skolbarn.

\section{Ett känt beteende}

Det tycks också som om det beteende som Heinemann beskrev med sitt begrepp upplevdes bekant av många. Den livliga mediadebatt som uppstod visar på att människor med termens hjälp kunde sätta ord på känslomässiga erfarenheter från den egna eller andras skoltid.

Helt oomtalad var inte företeelsen i skolsammanhang innan begreppet mobbning infördes, men man talade om det med andra ord och tolkade det på andra sätt. Längre tillbaks i tiden hade man talat om pennalism (Hall 1932, Norlin 2008). Jag har emellertid inte kunnat finna att pennalism var något allmänt omdiskuterat fenomen vid den tid då mobbningsbegreppet infördes (Larsson 2008b). Det var över huvud taget inte vanligt med problematiserande resonemang kring barns uteslutning av andra barn. När detta kom på tal uttrycktes det i termer av att vissa barn inte lyckades bli accepterade i kamratgrupper eller, vilket var relativt vanligt, att vissa barn var hackkycklingar. Uppmärksamheten låg i dessa fall främst på egenskaper hos såväl de angripande barnen som de drabbade. Ofta ansågs problemet ligga hos den drabbade individen:

Det kan finnas personlighetsdrag hos hackkycklingen som gör att han omedvetet drar på sig kamraternas elakheter. Ibland kan det $t$ o $m$ vara så att han omedvetet söker sig till svairigheter och konflikter. Bakom kan det ibland ligga undertryckta känslor av självhävdelse och trots, men samtidigt skuldkänslor för en egen önskan att slåss och bråka (Sylvander 1963: 293).

Ville man åstadkomma en förändring i situationen ansågs det vara den drabbade personen som på ett eller annat sätt behövde förändras:

Barn, som känner att de inte är accepterade av gruppen på grund av att de inte kan klara ett eller annat $i$ lek eller arbete, kan få en övning just $i$ detta och vinna en inre trygghet, så att de inte längre känner sig mindervärdiga på detta område, och därigenom bli godtagna i gruppen och komma in $i$ en helt annan social utveckling än tidigare (Skard 1952: 23-24).

När Heinemann (1969) beskriver mobbningsbeteendet känner många igen det samtidigt som hans förklaring är helt annorlunda. Han hävdar att mobbning i grunden är en uppladdad aggression i en grupp som utlöses närmast reflexartat när en person som kan fungera som »åskledare« råkar passera. Den aggressiva gruppen siktar lätt in sig på någon avvikelse hos denna person men det är rätt oviktigt vilken avvikelsen är. Heinemann fokuserar alltså mer på den angripande gruppen än på offret. Det fanns således bekanta aspekter i det nya mobbningsbegreppet samtidigt som det också innehöll helt nya aspekter. Förklaringsgrunden var ny liksom värderingen av fenomenet. 


\section{Begreppsintroduktionens betydelse}

Att begreppet myntades hade uppenbarligen en central betydelse. Termen mobbning satte ord på något som därmed lättare kunde uppmärksammas och problematiseras. Man kan säga att termen utgjorde ett slags strålkastare som lät ljuset falla på mobbningsfenomenet. Men termer och begrepp har också en tankestyrande funktion (Jordheim 2007: 79). Termen mobbning kan ses som en samlingsbeteckning, en kategoribenämning, som samlade och satte namn på ett antal beteenden som man i och för sig och i någon mån uppmärksammat var för sig men som med benämningen kunde börja betraktas som ingående i en gemensam klass av fenomen (Agevall 2008: 14). På ett liknande sätt fungerade begreppet miljö vid ungefär samma tid, det gav en kategoribenämning för ett antal olika företeelser och gjorde att ett antal problemöar kunde samlas till en "problemkontinent" (Thelander \& Lundgren 1989: 31). Analogt kunde sådant som tidigare beskrivits med hjälp av ord som hackkyckling, översitteri, att retas, att inte få vara med och så vidare nu sammanfattande uppfattas som mobbning.

Agevall (2008: 12-13) har noterat att mobbning till en början inte gavs någon definition utan formulerades genom ett antal exempel. Det fick till följd att många kunde bidra med nya exempel som i något avseende liknade de tidigare exemplen. Men eftersom likheten i exemplen kunde gälla vilken aspekt som helst kunde kategorin med mobbningsbeteenden växa snabbt och hade liksom ingen självklar yttre gräns.
Först så småningom etablerades en mer auktoritativ definition. En oklarhet om vilka beteenden som egentligen ska kallas mobbning har emellertid fortsatt att följa mobbningsdiskussionen i både media och vetenskap (Eriksson 2002: kap. 3). Även idag förefaller begreppet mobbning ha en tämligen vid innebörd både sett till dagens allmänna språkbruk och till de definitioner som numera används i olika sammanhang (Skolverket 2009). Men företeelsen blev ändå synlig och i någon mån avgränsad i och med att den fick en formulering.

Jag vill således hävda att introduktionen av det nya begreppet hade en mycket stor betydelse, dels genom att begreppet möjliggjorde ett samtal om något tidigare svårbeskrivet och dels genom att det styrde förståelsen av företeelsen i bestämda riktningar.

\section{Varför just då?}

Man kan även i vidare mening fundera över varför begreppet fick fäste just kring 1970. Här kan aspekter uppmärksammas som gäller skola, vetenskap och samhälle i samtidens Sverige. 1960-talets samhällsutveckling innebar en ökad heterogenitet i samhället som en följd av ökad social mobilitet, ökad invandring, fler adoptioner, kvinnors ökande deltagande på arbetsmarknaden och ett utbildningssystem under utbyggnad. Samtidigt fanns starka integreringsambitioner. Det successiva införandet av enhetsskolan och grundskolan under de första efterkrigsdecennierna vägleddes av tankar om en gemensam skola för alla barn. Under 1960-talet diskuterades hur 
skolans integrering av invandrare och handikappade skulle bli lyckosam. Många uppfattade att livet i skolan blivit mer socialt komplext (Larsson 2010, Marklund 1982: 375-385). I efterdyningarna av andra värlskriget hade, inte bara i skolsammanhang, frågor om ledarskap och uppfostran diskuterats, ofta i termer av den symbolladdade dikotomin auktoritärt-demokratiskt (se t.ex. Björklund \& Israel 1951, Hermansson 1952).

Vidare hade 1950- och 1960-talen sett ett kraftigt ökat intresse för det social- och beteendevetenskapliga området. Inom sociologin hade intresset för socialpsykologiska frågor kring gruppfenomen etablerats och spritts på olika plan (Larsson 2001). Psykologin, kanske särskilt den som gällde barn och uppfostran, hade sedan 1930-talet mötts av ett starkt intresse (Seifarth 2007: 162f). Klassrummet som ett socialt system hade fått en central roll i den sociometriska forskningsinriktning som utvecklats inom pedagogisk psykologi (se t.ex. Johannesson 1954, Bjerstedt 1963). Detta innebar att sociala relationer i familj, skola och samhälle uppmärksammades.

Det har också hävdats att det skedde en värderingsförskjutning under 1960-talet i synen på samhällets svaga och utsatta individer och grupper. I stället för att fokusera på individens skyldigheter gentemot samhället lyftes individens rättigheter fram. Uppfattningen stärktes att det var samhällets ansvar att hjälpa de utsatta (Larsson 1994: 223-226). Den tidigare tämligen starka grundtanken att individen måste anpassa sig till samhällets krav och förväntningar, började ersättas av ett synsätt som kanske kan beskrivas i termer av ett "individualiseringsparadigm", där anpassningskraven allt tydligare uppfattades som kränkningar av individens rätt till sina personliga särdrag och sina val.

En grupp vars rättigheter började stärkas var barnen. Vissa forskare har lyft fram ett skifte i synsätt på barn kring slutet av 1960-talet. Den dominerande idealbilden av barnet under 1950- och 1960-talen var ett fritt, frimodigt och muntert barn med livlig fantasi medan 1970-talets barnbild innebar att även barns "negativa» känslor fick (och skulle) släppas fram. Med detta skifte ersattes också en tidigare idyllisk familjebild av en ökad vardagsrealism, en större samhällsanknytning och en ökad problematisering av barns tillvaro (Rydin 2000: 343; Lindgren 2003: 186). Alla dessa omständigheter kan ha bidragit till en ökad uppmärksamhet på barns sociala liv och problematiseringen av mobbning.

\section{Mobbning som socialt problem: diskussion}

Jag vill alltså hävda att mobbning vid decennieskiftet 1970 blev ett socialt problem. Detta kan diskuteras, och blir särskilt tydligt, med hjälp av Meeuwisses och Swärds (2002a: 37-39) sammanfattning av hur sociala problem beskrivs och definieras. Den första definierande aspekten, att ett socialt problem har med den sociala sfären att göra, förefaller mer begreppslig än tidsbunden: mobbning måste förknippas med den sociala sfären hur än företeelsen uppfattas. Men sett till samtliga övriga sex aspekter förändrades situationen när mobbningsproblemet artikulerades. Till 
skillnad från den rådande värderingen måste mobbning betraktas som oacceptabelt, hävdade Heinemann, och med den efterföljande debatten i media spreds och befästes denna uppfattning. Tanken att mobbning inte bara är ett individuellt problem utan också ett samhälleligt var också en del i detta nya synsätt. Det är möjligt att lika många var drabbade av mobbning före 1969 men många ansåg att problemet hade ökat och Heinemann menade att det moderna storskaliga urbaniserade samhällets stora städer och stora skolor främjade mobbning. Debatten ledde också till att förekomsten av mobbning i skolorna började undersökas och konkreta siffror på frekvens och förekomst kunde presenteras. Uppfattningen att mobbning kan och bör åtgärdas och att ansvaret för detta inte ligger bara på individen utan på skola och samhälle uppkom också i samband med problemformuleringen. Att synligheten ökade är uppenbart, problemformuleringen innebar att företeelsen mobbning upptäcktes.

När mobbningsföreteelsen började uppmärksammas kan man alltså se detta som att problemet övergick från att ha varit latent till att bli manifest. Man kan också säga att det övergick från att ha varit ett individuellt problem till att bli ett socialt, från att ha varit ett problem för individen till att bli ett problem för skolan, arbetsplatsen eller samhället. Problemet blev synligt och det började anses nödvändigt (och möjligt) att åtgärda och ansvaret för åtgärderna övergick från individen eller familjen till samhället.

Något som är uppenbart, och som jag vill lyfta fram som ett resultat i förhål- lande till den teoretiska diskussionen, är begreppsformuleringens betydelse. Termen mobbning innebar att man kunde uppmärksamma och tala om fenomenet samtidigt som själva begreppsformuleringen innebar en styrning av tänkandet. Termen fungerade som en kategoribenämning och samlade ett antal fenomen till en gemensam klass som nu kunde uppfattas som sammanhängande. Trots begreppets tämligen vaga avgränsning möjliggjorde det ett samtal om något tidigare svårbeskrivet och skapade samtidigt en viss slags förståelse av fenomenet.

Låt mig så avslutningsvis återknyta till distinktionen mellan konstruerade och objektiva aspekter i mobbning som ett socialt problem. Jag har visat hur mobbningsproblemet konstruerades när det första gången artikulerades 1969. Jag har också berättat något om hur begreppet togs emot och diskuterat begreppsintroduktionens betydelse samt lyft fram några tänkbara historiska skäl till att mobbning uppmärksammades. Den snabba acceptansen av mobbningsbegreppet, utvecklingen av ett forskningsområde kring mobbning och den periodvis livliga och ännu pågående mediadebatten tyder emellertid på att mobbning var ett problemområde som fanns latent och som för att bli synliggjort "behövde" en term med potential att inrymma och artikulera företeelsen. På det sättet tycks det relevant att tänka sig mobbning som ett objektivt existerande problem vare sig individer eller samhället insett detta. Det är emellertid också påtagligt hur problemet konstrueras genom hur det beskrivs och att olika problembeskrivningar möjliggör olika uppfattningar om vems problemet är, hur 
det avgränsas och hur man kan åtgärda det. Sett på detta sätt är mobbning ett socialt problem som konstruerades kring decennieskiftet 1970. Jag tror att det är mindre fruktbart att begränsa sig till en utgångspunkt som är antingen objektivistisk eller konstruktionistisk. I stället bör man beakta både objektiva och konstruerade aspekter, vill jag hävda, när man analyserar mobbning som ett socialt problem. Med all sannolikhet gäller detta även andra sociala problem.

\section{Referenser}

Agevall, Ola (2007) »Mobbning, interaktion och meningsproduktion. Lokala kulturer, individuella trakasserier och kategoriell uteslutning». I Mikael Carleheden, Rolf Lidskog \& Christine Roman (red.) Social interaktion: förutsättningar och former Malmö: Liber.

Agevall, Ola (2008) The Career of Mobbing. Emergence, Transformation, and Utilisationof a New Concept. Växjö: Institutionen för samhällsvetenskap, Växjö universitet.

Bash, Harry H. (1995) Social Problems and Social Movements. An Exploration into the Sociological Construction of Alternative Realities. New Jersey: Humanities Press.

Bjerstedt, Åke (1963) Sociometriska metoder. Stockholm: Almqvist \& Wiksell.

Björklund, Eskil \& Joachim Israel (1951) The Authoritarian Ideology of Upbringing. Uppsala.

Björkqvist, Kaj \& Lasse Varhama (2008) „Parallells between Bullying in Schools and in Workplaces.

A Comparative Review Based Primarily on Scandinavian Research". I Lasse Varhama Bullying and other Dysfunctional Behaviour at the Workplace and at School. Åbo: Åbo Akademi University Press.

Dagens Nyheter (1970) „Mobbing. En artikelserie om gruppvåld mot avvikande barn«. Stockholm: Dagens Nyheter.

Eriksson, Björn (2001) "Mobbning: en sociologisk diskussion". Sociologisk forskning nr 2, s. 8-44.

Eriksson, Björn et al. (2002) Skolan - en arena för mobbning. En forskningsöversikt och diskussion kring mobbning i skolan. Stockholm: Skolverket.

Edling, Nils (1996) Det fosterländska hemmet. Egnahemspolitik, småbruk och hemideologi kring sekelskiftet 1900. Stockholm: Carlssons.

Estrada, Felipe (1999) Ungdomsbrottslighet som samhällsproblem. Utveckling, uppmärksamhet och reaktion. Stockholm: Kriminologiska institutionen, Stockholms universitet.

Fors, Zelma (1993) Obalans i makt. Fallstudier av barnmobbning. Göteborg: Psykologiska institutionen, Göteborgs universitet.

Hagerfors Anna-Maria \& Birgitta Nyblom (1969a) "Det börjar med en hackkyckling...", Dagens Nyheter 13/11.

Hagerfors Anna-Maria \& Birgitta Nyblom (1969b) "Skolgårdens hårda värld", Dagens Nyheter $16 / 11$.

Hagerfors Anna-Maria \& Birgitta Nyblom (1969c) "Hänsyn måste stå på schemat': Och det gör det här", Dagens Nyheter 19/11.

Hagerfors Anna-Maria \& Birgitta Nyblom (1969d) "Forska mer om mobbing - samlevnad är skolämne'", Dagens Nyheter 23/11.

Hagerfors Anna-Maria \& Birgitta Nyblom (1969e) "På schemat: 'Förståelse för nästan'", Dagens Nyheter 29/11.

Hagerfors Anna-Maria \& Birgitta Nyblom (1969f) "Medlidande räcker inte för att hindra mobbing", Dagens Nyheter 2/12. 
Hall, Rudolf B. (1932) Gammaldags penalism vid läroverken. Primärkällor och skildringar. Lund: Föreningen för svensk undervisningshistoria.

Hegelbach, Johann (2003) »Mobbing - ein Begriff des 20. Jahrhunderts". Der Ornithologische Beobachtervol. $100 \mathrm{nr}$ 1, s. 9-15.

Heinemann, Peter Paul (1969) "Apartheid», Liberal debattnr 2, s. 3-14.

Hermansson, Ester (red) (1952) Social fostran. En handbok för lärare. Stockholm: Bonniers.

Johannesson, Ingvar (1954) Studier av sociala relationer mellan barn i folkskoleklasser. Lund: Gleerup.

Jordheim, Helge (2007) »Thinking in Convergences. Koselleck on Language, History and Time». Ideas In History vol. $2 \mathrm{nr}$ 3, s. 65-90.

King, Erika G. (1994) „Crowd psychology». I Encyclopedia of Human Behavior, vol 2. San Diego \& London: Academic Press.

Larsson, Anna (2010) »Mobbningsfrågan i förändring: Efterkrigstidens synsätt på skolbarns kamratliv", Historisk tidskrift 130:2 (2010), 241-264.

Larsson, Anna (2008a) „Fåglar i klassrummet. Mobbning och hackordning som gränsöverskridande metaforeru. I Bosse Sundin \& Maria Göransdotter (red.) Mångsysslare och gränsöverskridare. 13 uppsatser i idéhistoria. Umeå: Umeå universitet.

Larsson, Anna (2008b) „Mobbningsbegreppets uppkomst och förhistoria. En begreppshistorisk analys". Pedagogisk forskning i Sverige vol. $13 \mathrm{nr} 2$, s. 19-36.

Larsson, Anna (2001) Det moderna samhällets vetenskap. Om etableringen av sociologi $i$ Sverige 1930-1955. Umeå: Umeå universitet.

Larsson, Jan (1994) Hemmet vi ärvde. Omfolkhemmet, identiteten och den gemensamma framtiden. Stockholm: Arena.

Leymann, Heinz (1986) Vuxenmobbning. Om psykiskt vaild i arbetslivet. Lund: Studentlitteratur.

Lindgren, Anne-Li (2003) „Att ha fokus på barns aktivitet. Hur förskolebarndomen blev norm i väldfärdsstaten«. I Bengt Sandin \& Gunilla
Halldén (red.) Barnets bästa. En antologi om barndomens innebörder och välfärdens organisering. Stockholm/Stehag: Symposion.

Lindgren, Sven-Åke (1993) Den hotfulla njutningen: Att etablera drogbruk som samhällsproblem 1890-1970. Stockholm/Stehag: Symposion.

Lorenz, Konrad (1967) Aggression: Dess bakgrund och natur. Stockholm: Norstedt.

Loseke, Donileen R. \& Joel Best (red.) (2003) Social Problems: Constructionist Readings. New York: Aldine de Gruyter.

Loseke, Donileen R. (2003) Thinking About Social Problems: An Introduction to Constructionist Perspectives. New York: Aldine de Gruyter.

Macklem, Gayle L. (2003), Bullying and Teasing: Social Power in Children's Groups. New York: Kluwer Academic/Plenum Publishers.

Marklund, Sixten (1982) Skolsverige 1950-1975. Del 3. Från Visbykompromissen till SIA. Stockholm: Skolöverstyrelsen och Läromedelsförlaget.

Meeuwisse, Anna \& Swärd, Hans (2002a) „Vad är ett socialt problem?». I Anna Meeuwisse \& Hans Swärd (red.) Perspektiv på sociala problem. Stockholm: Natur och kultur.

Meeuwisse, Anna \& Swärd, Hans (2002b) „Perspektiv på sociala problem - några positioner". I Anna Meeuwisse \& Hans Swärd (red.) Perspektiv på sociala problem. Stockholm: Natur och kultur.

Merton, Robert K. \& Robert A. Nisbet (eds) (1966) Contemporary Social Problems, 2. Ed. New York: Harcourt Brace Jovanovich.

Mills, C. Wright (1985) Den sociologiska visionen. Lund: Arkiv förlag.

Nilsson, Roddy (2003) Kontroll, makt och omsorg. Sociala problem och socialpolitik $i$ Sverige 1780-1940. Lund: Studentlitteratur.

Norlin, Björn (2008) „Kamratuppfostran och subordination. Om våldet vid svenska gymnasier under tidigt 1800-tal«. I Esbjörn Larsson (red.) Ny utbildningshistorisk forskning. Tio bidrag från nationella forskarskolan $i$ utbildningshistoria. Uppsala: Föreningen för svensk undervisningshistoria.

Olofsson, Jonas (1997) »Idéer om arbetslöshet och 
social politik vid 1800-talets mitt". Socialvetenskaplig tidskrift vol. $4 \mathrm{nr}$ 3, s. 216-235.

Olweus, Dan (1973) Hackkycklingar och översittare. Forskning om skolmobbning. Stockholm: Almqvist \& Wiksell.

Panelius, Olav \& Torsten Steinby (1970) Svenska modeord. Lund: Gleerup.

Roland, Erling \& Elaine Munthe (red) (1989) Bullying. An International Perspective. London: David Fulton.

Roland, Roland (1988) „Bullying. The Scandinavian Research Tradition«. I Delwyn P. Tattum \& David A. Lane (red.) Bullying in schools. London: Trentham books.

Rubington, Earl \& Weinberg, Martin S. (red.) (2003) The Study of Social Problems. Seven Perspectives, $6^{\text {th }}$ ed. New York \& Oxford, Oxford University Press.

Rydin, Ingegerd (2000) Barnens röster. Program för barn i Sveriges radio och television 1925-1999. Stockholm: Stiftelsen etermedierna i Sverige.

Sahlin, Ingrid (2002) „Sociala problem som verklighetskonstruktioner». I Anna Meeuwisse \& Hans Swärd (red.) Perspektiv på sociala problem. Stockholm: Natur och kultur.

Seifarth, Sofia (2007) Råd i radion. Modernisering, allmänhet och expertis 1939-1968. Stock- holm: Carlsson.

Skard, Åse Gruda (1952) "Social utveckling och personlighetsdaning". I Ester Hermansson (red.) Social fostran. En handbok för lärare. Stockholm: Bonniers.

Skolverket (2009) På tal om mobbning - och det som görs. Stockholm: Skolverket.

Smith, Peter K. \& Sonya Sharp (red.) (1994) School Bullying. Insights and Perspectives. London: Routledge.

Smith, Peter K et al (red.) (1999) The Nature of School Bullying: A Cross-National Perspective. London \& New York: Routledge.

Sylvander, Inga (1963) „Vanliga barn och ovanliga». I Lis Asklund \& Maj Ödman (red.) Föräldraboken. Utgiven under medverkan av Sveriges främsta experter ibarnuppfostrings- och familjefrågor till alla föräldrars hjälp. Malmö: Bernces förlag.

Swärd, Hans (2008) Hemlöshet. Lund: Studentlitteratur.

Thelander, Jan \& Lars J. Lundgren (1989) Nedräkning pågår. Hur upptäcks miliöproblem? Vad händer sen? Stockholm: Naturvårdsverket.

Varhama, Lasse (2008) Bullying and other Dysfunctional Behaviour at the Workplace and at School. Åbo: Åbo Akademi University Press.

Anna Larsson: Mobbning: ett tidsbundet socialt problem? 


\section{Summary}

\section{"Mobbning" A Social Problem in Time?}

Today, bullying is considered a serious and important problem in schools as well as in working life. This has not always been the case, however. In Sweden, a new concept, "mobbning", was introduced in 1969. This concept focused on, framed and drew attention to the problematic aspects of bullying among children and established bullying in schools as a social problem for parents, schools and society to handle.

The aim of this article is to discuss the emergence of the social problem of bullying with special focus on its conceptualization. A theoretical starting point is taken in theories about social problems in general. As many researchers have concluded, there is no obvious definition of a social problem, and what is considered as a social problem varies in time. Many agree that there are usually both objective and constructed aspects in a social problem. This article shows how the problem of bullying was constructed when it was articulated in 1969 and how it was received and discussed in media. Some historical reasons for the interest in bullying are presented. The quick acceptance and spreading of the concept of "mobbning", the development of a field of research and the keen media debate implies that bullying was a latent problem that needed a concept to come into view. In this way, bullying seems to be an objective problem regardless of whether people or society recognize it. It is also obvious, however, that the articulation of it made bullying in schools a social problem and influenced how it was understood. 